\title{
Technical Factors Influencing to Production of Galangal-Pickled Shrimp (Litopenaeus Vannamei)
}

\author{
NGUYEN PHUOC MINH ${ }^{1 *}$, PHAM THI LE PHA ${ }^{2}$, NGUYEN HONG THAM ${ }^{3}$ \\ and NGUYEN THI VAN LINH ${ }^{4}$
}

${ }^{1}$ Faculty of Chemical Engineering and Food Technology, Nguyen Tat Thanh University, Ho Chi Minh, Vietnam. ${ }^{2}$ Vinh Hau Secondary School, Hoa Binh District, Bac Lieu Province, Vietnam.

${ }^{3}$ Le Hong Phong Secondary - High School, Soc Trang Province, Vietnam.

${ }^{4}$ NTT Hi-Tech Institute, Nguyen Tat Thanh University, Ho Chi Minh City, Vietnam.

*Corresponding author E-mail: ts.nguyenphuocminh@gmail.com

http://dx.doi.org/10.13005/ojc/350157

(Received: November 08, 2018; Accepted: December 03, 2018)

\section{ABSTRACT}

\begin{abstract}
White shrimp (Litopenaeus vannamei) is a very important food due to high protein content and nutritional value. Galanga (Alpinia galanga) is highly evaluated as their specific flavor and aroma as well as plenty healthy effects. Fermentation is considered as a common approach in food storage; it contributes an essential duty in improvement of nutritional and functional characteristic of foodstuff. Pickled shimp has good source of peptides and amino acids. Therefore, objective of this research focused on different chemical/ technical aspects such as the effect of $\mathrm{NaCl}, \mathrm{CaCl}_{2}$, sugar and ethanol concentration used for primary treatment; galangal ratio mixing with shrimp, fermentation temperature and time influencing to the amino acid content, $\mathrm{pH}$, water activity and sensory characteristics galangal-pickled shrimp. Results revealed that $15 \%$ of $\mathrm{NaCl}, 2.0 \%$ of $\mathrm{CaCl}_{2}, 10 \%$ of sucrose, $8 \%$ of ethanol addition together with $10 \%$ sliced galangal in shrimp mixture; fermentation at $28^{\circ} \mathrm{C}$ for 28 days, the final galangal-pickled shrimp had the good a pleasant taste and appearance. This delicious pickled shrimp was highly welcomed by customers.
\end{abstract}

Keywords: White shrimp, Galangal, Salt, Sugar, Ethanol, Pickle.

\section{INTRODUCTION}

White shrimp (Litopenaeus vannamei) is one of the key brackish water species in Vietnamese shrimp farming. Vietnamese farmers move away from farming black tiger shrimp (Penaeus monodon) and change to the cheaper white shrimp (Litopenaeus vannamei). Regarding to nutritive compostion of raised white leg shrimp Litopenaeus vannamei, it has good source of protein, carbohydrate, lipid, moisture and ash, calcium, sodium, potassium, manganese, copper, chromium ${ }^{1}$. Shrimps have low fat, less cholesterol and high PUFA content ${ }^{2}$.

Galanga (Alpinia galanga) is a plant in the ginger family. Galangal is highly evaluated for their specific flavor and aroma. Various parts of this plant are utilized in the treatment of many diseases ${ }^{3}$.

This is an Open Access article licensed under a Creative Commons license: Attribution 4.0 International (CC- BY). Published by Oriental Scientific Publishing Company @ 2018

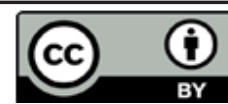


Alpinia galanga contained flavonoids and volatile $\mathrm{oil}^{4,5}$. Galangal is used as an alternative to replace antibiotics applied in shrimp farming ${ }^{6}$.

Fermented products from white shrimp (Litopenaeus vannamei) such as fermented shrimp paste, pickled shrimp are widely consumed in Vietnam. Fermented shrimps imparted delicacy and high nutritional properties ${ }^{7}$. Regarding to production of fermented shrimp paste, there were serveral outstanding researches. Shrimp was mixed with salt to ferment shrimp paste ${ }^{8}$. Lentibacillus kapialis sp. produced a red color in sodium chloride during shrimp paste fermentation ${ }^{9}$. Fermented shrimp products could be considered as umami ${ }^{10}$. Quality characteristics in different shrimp paste were compared ${ }^{11}$. The changes in the biochemical, nutritional, and sensory properties of the shrimp paste during fermentation were studied ${ }^{12}$.

The seafood pickle has good composition of protein, glycogen and minerals compared with vegetable one ${ }^{13,14,15}$. There were several researches mentioned to the production of pickle seafood. Total viable count in prawn pickle in the range of 103-105 per g was reported ${ }^{16}$. Microorganisms associated with spoilage of prawn pickle was studied ${ }^{17}$. Microbiological characteristics of prawn pickle. Staphylococcus was reported in spoiled prawn pickle was examined ${ }^{18}$. The pickled prawn was produced ${ }^{19}$. The firmness in prawns (Machrobrachium rosenbergii) marinated in $\mathrm{NaCl}$ and acidity was evaluated ${ }^{20}$. The white shrimp (Litopenaeus vannamei) was marinated with green curry to produced shrimp paste marinade ${ }^{21}$. The effects of different temperature and time during pasteurization on marinated green curry shrimp were examined ${ }^{22}$. However, there was not any research mentioned to production of pickle white shrimp (Litopenaeus vannamei). Therefore, objective of this research focused on different technical aspects such as the effect of $\mathrm{NaCl}, \mathrm{CaCl}_{2}$, sucrose and ethanol concentration used for primary treatment; galangal ratio mixing with shrimp, fermentation temperature and time influencing to the amino acid content, $\mathrm{pH}$, water activity and sensory characteristics galangal-pickled shrimp.

\section{MATERIALS AND METHOD}

\section{Material}

We collected white shrimp (Litopenaeus vannamei) from Hoa Binh district, Bac Lieu province, Vietnam. They must be reared following VietGAP to ensure food safety. After collecting, they must be temporarily preserved by flake ice and conveyed to laboratory within $4 \mathrm{~h}$ for experiments. They were washed and sanitized under washing tank having $25 \mathrm{ppm}$ chlorine with a support of air bubble blowing to remove foreign matters. Besides Litopenaeus vannamei we also used another material during the research such as chlorine, $\mathrm{NaCl}, \mathrm{CaCl}_{2}$, sucrose, ethanol, galanga, glass bottle. Lab. utensils and equipments included digital digital weight balance, water activity meter, $\mathrm{pH}$ meter, membrane filter, amino acid analyzer, and fermentor.

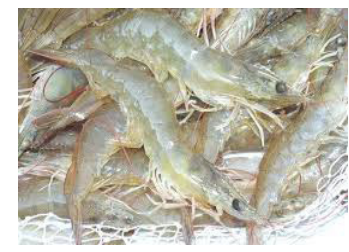

(a)

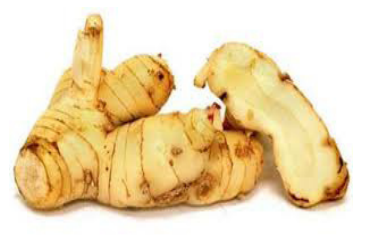

(b)

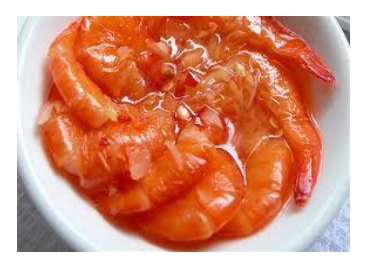

(c)

Fig. 1. (a) Raw white shrimp (Litopenaeus vannamei), (b) galangal (Alpinia galanga), (c) pickled white shrimp (Litopenaeus vannamei)

Effect of $\mathrm{NaCl}, \mathrm{CaCl}_{2}$, sucrose, ethanol concentration to amino acid, $\mathrm{pH}$, water activity and sensory score of the galanga-pickled white shrimp (Litopenaeus vannamei)

White shrimps (Litopenaeus vannamei) were treated with different ratios: $\mathrm{NaCl}(5 \%, 10 \%$, $15 \%, 20 \% 25 \%), \mathrm{CaCl}_{2}(1 \%, 1.5 \%, 2.0 \%, 2.5 \%$, $3.0 \%$ ), sucrose $(5 \%, 10 \%, 15 \%, 20 \%, 25 \%)$, ethanol $(2 \%, 4 \%, 6 \%, 8 \%, 10 \%)$, sliced galanga $(5 \%, 10 \%$, $15 \%, 20 \%, 25 \%$ ) to create a pleasant taste and appearance of galanga-pickled white shrimp. All samples fermented at $30^{\circ} \mathrm{C}$ in 26 days. Five galangapickled white shrimps were chosen randomly to analyse amino acid (g/100g), pH, water activity (aw), and sensory score. 
Effect of fermentation temperature and time to amino acid, $\mathrm{pH}$, water activity and sensory score of the galanga-pickled white shrimp (Litopenaeus vannamei)

White shrimps (Litopenaeus vannamei) were treated with different ratios: $\mathrm{NaCl}(5 \%, 10 \%$, $15 \%, 20 \% 25 \%), \mathrm{CaCl}_{2}(1 \%, 1.5 \%, 2.0 \%, 2.5 \%$, $3.0 \%)$, sucrose $(5 \%, 10 \%, 15 \%, 20 \%, 25 \%)$, ethanol $(2 \%, 4 \%, 6 \%, 8 \%, 10 \%)$, sliced galanga $(5 \%, 10 \%$, $15 \%, 20 \%, 25 \%$ ) to create a pleasant taste and appearance of galanga-pickled white shrimp. All samples fermented different temperature and time $\left(26^{\circ} \mathrm{C}\right.$ in 30 days, $28^{\circ} \mathrm{C}$ in 28 days, $30^{\circ} \mathrm{C}$ in 26 days, $32^{\circ} \mathrm{C}$ in 24 days, $34^{\circ} \mathrm{C}$ in 22 days). Five galangapickled white shrimps were chosen randomly to analyse amino acid (g/100 g), pH, water activity (aw), and sensory score.

Shelf-life of the galanga-pickled white shrimp (Litopenaeus vannamei) during storage

Galanga-pickled white shrimp (Litopenaeus vannamei) products were kept in ambient temperature condition $\left(28 \pm 2^{\circ} \mathrm{C}\right)$. Amino acid $(\mathrm{g} / 100 \mathrm{~g}), \mathrm{pH}$, water activity (aw), sensory score were used as quality indicators by sampling in 3 months interval for 12 months.

Physico-chemical, microbial and sensory analysis

Amino acid was measured by using an amino acid analyzer. $\mathrm{pH}$ of samples was measured using a pH meter. Water activity was assessed by using a water activity meter. Sensory score of fermented shrimp (Litopenaeus vannamei) paste was assessed by a group of panelist using the 9-point hedonic scale.

\section{Statistical analysis}

The experiments were performed in triplicate. Statistical analysis was based on the Startgraphics.

\section{RESULT \& DISCUSSION}

Effect of $\mathrm{NaCl}, \mathrm{CaCl}_{2}$, sucrose, ethanol, sliced galanga ratio supplemented to shrimp mixture to amino acid, $\mathrm{pH}$, water activity and sensory score of the galanga-pickled white shrimp (Litopenaeus vannamei)

White shrimps (Litopenaeus vannamei) were treated with different ratios: $\mathrm{NaCl}(5 \%, 10 \%, 15 \%, 20 \%$ $25 \%), \mathrm{CaCl}_{2}(1 \%, 1.5 \%, 2.0 \%, 2.5 \%, 3.0 \%)$, sucrose (5\%, $10 \%, 15 \%, 20 \%, 25 \%)$, ethanol $(2 \%, 4 \%, 6 \%$, $8 \%, 10 \%)$, sliced galanga ( $5 \%, 10 \%, 15 \%, 20 \%, 25 \%$ ) to create a pleasant taste and appearance of galangapickled white shrimp. All samples fermented at $30^{\circ} \mathrm{C}$ in 26 days. Five galanga-pickled white shrimps were chosen randomly to analyse amino acid (g/100g), pH, water activity (aw), and sensory score. From Table 1 , $2,3,4,5$; the best quality of galanga-pickled white shrimp (Litopenaeus vannamei) would be achieved by $15 \%$ of $\mathrm{NaCl}, 2.0 \%$ of $\mathrm{CaCl}_{2}, 10 \%$ of sucrose, $8 \%$ of ethanol addition together with $10 \%$ sliced galangal in shrimp mixture.

Table 1: Effect of $\mathrm{NaCl}$ concentration to amino acid, $\mathrm{pH}$, water activity and sensory score of the galanga-pickled white shrimp (Litopenaeus vannamei)

\begin{tabular}{ccccc}
\hline $\mathrm{NaCl}$ & Amino acid $(\mathrm{g} / 100 \mathrm{~g})$ & $\mathrm{pH}$ & Water activity $\left(\mathrm{a}_{\mathrm{w}}\right)$ & Sensory score \\
\hline $5 \%$ & $41.69 \pm 0.03^{\mathrm{e}}$ & $5.87 \pm 0.01^{\mathrm{a}}$ & $0.74 \pm 0.01^{\mathrm{a}}$ & $5.22 \pm 0.01^{\mathrm{c}}$ \\
$10 \%$ & $42.17 \pm 0.01^{\mathrm{d}}$ & $5.29 \pm 0.02^{\mathrm{b}}$ & $0.72 \pm 0.01^{\mathrm{ab}}$ & $6.39 \pm 0.02^{\mathrm{b}}$ \\
$15 \%$ & $45.36 \pm 0.00^{\mathrm{a}}$ & $4.56 \pm 0.00^{\mathrm{d}}$ & $0.68 \pm 0.03^{\mathrm{b}}$ & $7.45 \pm 0.01^{\mathrm{a}}$ \\
$20 \%$ & $44.10 \pm 0.01^{\mathrm{b}}$ & $5.03 \pm 0.03^{\mathrm{c}}$ & $0.65 \pm 0.02^{\mathrm{bc}}$ & $6.29 \pm 0.02^{\mathrm{b}}$ \\
$25 \%$ & $43.29 \pm 0.02^{\mathrm{c}}$ & $5.21 \pm 0.02^{\mathrm{bc}}$ & $0.62 \pm 0.01^{\mathrm{c}}$ & $5.47 \pm 0.02^{\mathrm{c}}$ \\
\hline
\end{tabular}

Note: the values were expressed as the mean of three repetitions; the same characters (denoted above), the difference between them was not significant ( $\alpha=5 \%$ ).

Table 2: Effect of $\mathrm{CaCl}_{2}$ concentration to amino acid, $\mathrm{pH}$, water activity and sensory score of the galanga-pickled white shrimp (Litopenaeus vannamei)

\begin{tabular}{ccccc}
\hline $\mathrm{CaCl}_{2}$ & Amino acid $(\mathrm{g} / 100 \mathrm{~g})$ & $\mathrm{pH}$ & Water activity $\left(\mathrm{a}_{\mathrm{w}}\right)$ & Sensory score \\
\hline $1.0 \%$ & $45.36 \pm 0.01^{\mathrm{c}}$ & $4.56 \pm 0.01^{\mathrm{b}}$ & $0.68 \pm 0.02^{\mathrm{a}}$ & $7.45 \pm 0.02^{\mathrm{b}}$ \\
$1.5 \%$ & $45.88 \pm 0.02^{\mathrm{b}}$ & $4.58 \pm 0.03^{\mathrm{ab}}$ & $0.67 \pm 0.02^{\mathrm{ab}}$ & $7.66 \pm 0.01^{\mathrm{ab}}$ \\
$2.0 \%$ & $46.13 \pm 0.01^{\mathrm{ab}}$ & $4.60 \pm 0.00^{\mathrm{ab}}$ & $0.66 \pm 0.03^{\mathrm{ab}}$ & $7.97 \pm 0.01^{\mathrm{a}}$ \\
$2.5 \%$ & $46.17 \pm 0.03^{\mathrm{a}}$ & $4.63 \pm 0.02^{\mathrm{ab}}$ & $0.64 \pm 0.00^{\mathrm{b}}$ & $7.22 \pm 0.01^{\mathrm{bc}}$ \\
$3.0 \%$ & $46.20 \pm 0.02^{\mathrm{a}}$ & $4.65 \pm 0.01^{\mathrm{a}}$ & $0.63 \pm 0.03^{\mathrm{b}}$ & $6.59 \pm 0.04^{\mathrm{c}}$ \\
\hline
\end{tabular}

Note: the values were expressed as the mean of three repetitions; the same characters (denoted above), the difference between them was not significant $(\alpha=5 \%)$. 
Table 3: Effect of sucrose concentration to amino acid, $\mathrm{pH}$, water activity and sensory score of the galanga-pickled white shrimp (Litopenaeus vannamei)

\begin{tabular}{ccccc}
\hline Sucrose & Amino acid $(\mathrm{g} / 100 \mathrm{~g})$ & $\mathrm{pH}$ & Water activity $\left(\mathrm{a}_{\mathrm{w}}\right)$ & Sensory score \\
\hline $5 \%$ & $46.13 \pm 0.01^{\mathrm{b}}$ & $4.60 \pm 0.00^{\mathrm{a}}$ & $0.66 \pm 0.03^{\mathrm{a}}$ & $7.97 \pm 0.01^{\mathrm{b}}$ \\
$10 \%$ & $47.94 \pm 0.04^{\mathrm{a}}$ & $4.43 \pm 0.02^{\mathrm{b}}$ & $0.65 \pm 0.01^{\mathrm{ab}}$ & $8.24 \pm 0.03^{\mathrm{a}}$ \\
$15 \%$ & $45.21 \pm 0.02^{\mathrm{c}}$ & $4.42 \pm 0.01^{\mathrm{bc}}$ & $0.63 \pm 0.04^{\mathrm{b}}$ & $7.35 \pm 0.01^{\mathrm{bc}}$ \\
$20 \%$ & $45.01 \pm 0.01^{\mathrm{cd}}$ & $4.40 \pm 0.04^{\mathrm{bc}}$ & $0.62 \pm 0.02^{\mathrm{bc}}$ & $7.01 \pm 0.02^{\mathrm{c}}$ \\
$25 \%$ & $44.79 \pm 0.04^{\mathrm{d}}$ & $4.39 \pm 0.02^{\mathrm{c}}$ & $0.60 \pm 0.02^{\mathrm{c}}$ & $6.56 \pm 0.02^{\mathrm{d}}$ \\
\hline
\end{tabular}

Note: the values were expressed as the mean of three repetitions; the same characters (denoted above), the difference between them was not significant $(\alpha=5 \%)$.

Table 4: Effect of ethanol concentration to amino acid, $\mathrm{pH}$, water activity and sensory score of the galanga-pickled white shrimp (Litopenaeus vannamei)

\begin{tabular}{ccccc}
\hline Ethanol concentration & Amino acid $(\mathrm{g} / 100 \mathrm{~g})$ & $\mathrm{pH}$ & Water activity $\left(\mathrm{a}_{\mathrm{w}}\right)$ & Sensory score \\
\hline $2 \%$ & $47.94 \pm 0.04^{\mathrm{b}}$ & $4.43 \pm 0.02^{\mathrm{bc}}$ & $0.65 \pm 0.01^{\mathrm{a}}$ & $8.24 \pm 0.03^{\mathrm{b}}$ \\
$4 \%$ & $48.55 \pm 0.02^{\mathrm{a}}$ & $4.42 \pm 0.01^{\mathrm{c}}$ & $0.64 \pm 0.04^{\mathrm{ab}}$ & $8.58 \pm 0.02^{\mathrm{a}}$ \\
$6 \%$ & $47.30 \pm 0.03^{\mathrm{bc}}$ & $4.46 \pm 0.03^{\mathrm{b}}$ & $0.63 \pm 0.02^{\mathrm{b}}$ & $8.36 \pm 0.02^{\mathrm{ab}}$ \\
$8 \%$ & $47.07 \pm 0.00^{\mathrm{cc}}$ & $4.48 \pm 0.02^{\mathrm{ab}}$ & $0.61 \pm 0.01^{\mathrm{bc}}$ & $8.01 \pm 0.01^{\mathrm{bc}}$ \\
$10 \%$ & $46.49 \pm 0.02^{\mathrm{d}}$ & $4.51 \pm 0.00^{\mathrm{a}}$ & $0.60 \pm 0.03^{\mathrm{c}}$ & $7.95 \pm 0.04^{\mathrm{c}}$ \\
\hline
\end{tabular}

Note: the values were expressed as the mean of three repetitions; the same characters (denoted above), the difference between them was not significant $(\alpha=5 \%)$.

Table 5: Effect of sliced galanga ratio supplemented to shrimp mixture to amino acid, $\mathrm{pH}$, water activity and sensory score of the galanga-pickled white shrimp (Litopenaeus vannamei)

\begin{tabular}{ccccc}
\hline Galanga ratio & Amino acid $(\mathrm{g} / 100 \mathrm{~g})$ & $\mathrm{pH}$ & Water activity $\left(\mathrm{a}_{\mathrm{w}}\right)$ & Sensory score \\
\hline $5 \%$ & $48.55 \pm 0.02^{\mathrm{b}}$ & $4.42 \pm 0.01^{\mathrm{a}}$ & $0.64 \pm 0.04^{\mathrm{a}}$ & $8.58 \pm 0.02^{\mathrm{bc}}$ \\
$10 \%$ & $48.59 \pm 0.00^{\mathrm{ab}}$ & $4.39 \pm 0.02^{\mathrm{ab}}$ & $0.63 \pm 0.02^{\mathrm{ab}}$ & $8.76 \pm 0.01^{\mathrm{ab}}$ \\
$15 \%$ & $48.63 \pm 0.01^{\mathrm{ab}}$ & $4.35 \pm 0.01^{\mathrm{b}}$ & $0.63 \pm 0.01^{\mathrm{ab}}$ & $8.62 \pm 0.01^{\mathrm{ab}}$ \\
$20 \%$ & $48.70 \pm 0.03^{\mathrm{ab}}$ & $4.33 \pm 0.04^{\mathrm{bc}}$ & $0.60 \pm 0.03^{\mathrm{b}}$ & $8.60 \pm 0.04^{\mathrm{b}}$ \\
$25 \%$ & $48.73 \pm 0.01^{\mathrm{a}}$ & $4.31 \pm 0.01^{\mathrm{c}}$ & $0.60 \pm 0.00^{\mathrm{b}}$ & $8.44 \pm 0.02^{\mathrm{c}}$ \\
\hline
\end{tabular}

Note: the values were expressed as the mean of three repetitions; the same characters (denoted above), the difference between them was not significant $(\alpha=5 \%)$.

Rainbow Sardines and mackerel were pickled according to this cure, salt ratio adopted being $1: 3$ by weight of fish $^{23}$. Salt concentration $1.0-3.5 \%$ and acetic acid $1-2 \%$, the stability of pickled fish was low $^{24}$. The firmness of marinated prawns (Machrobrachium rosenbergii) in various $\mathrm{NaCl}$ and acidity was evaluated. $\mathrm{CaCl}_{2}$ and citrate solutions sightly accelerated the firmness of cooked prawn comparing with control. Tripolyphosphate didn't show effect while $\mathrm{CaCl}_{2}$, citric acid and lemon juice accelerated the muscle firmness ${ }^{20}$.

Nowa days people prepared seafood pickle by using organic solution with $\mathrm{NaCl}$ and spices ${ }^{25}$. Green curry paste marinade for white shrimp (Litopenaeus vannamei) with additional amount of garlic was was investigated to satisfy consumer acceptability ${ }^{21}$. The effects of different temperature and time during pasteurization of marinated shrimp in green curry were evaluated. The treated shrimp was mixed with green curry paste with shrimp to green curry paste ratio $2: 1(w / w)^{22}$.

Effect of fermentation temperature and time to amino acid, $\mathrm{pH}$, water activity and sensory score of the galanga-pickled white shrimp (Litopenaeus vannamei)

White shrimps (Litopenaeus vannamei) were treated with different ratios: $\mathrm{NaCl}(5 \%, 10 \%$, $15 \%, 20 \% 25 \%), \mathrm{CaCl}_{2}$ (1\%, 1.5\%, 2.0\%, 2.5\%, $3.0 \%)$, sucrose $(5 \%, 10 \%, 15 \%, 20 \%, 25 \%)$, ethanol (2\%, 4\%, 6\%, 8\%, 10\%), sliced galanga (5\%, 10\%, $15 \%, 20 \%, 25 \%)$ to create a pleasant taste and 
appearance of galanga-pickled white shrimp. All samples fermented different temperature and time $\left(26^{\circ} \mathrm{C}\right.$ in 30 days, $28^{\circ} \mathrm{C}$ in 28 days, $30^{\circ} \mathrm{C}$ in 26 days, $32^{\circ} \mathrm{C}$ in 24 days, $34^{\circ} \mathrm{C}$ in 22 days). Five galangapickled white shrimps were chosen randomly to analyse amino acid $(\mathrm{g} / 100 \mathrm{~g}), \mathrm{pH}$, water activity $\left(\mathrm{a}_{\mathrm{w}}\right)$, and sensory score. From Table 6, the fermentation process should be conducted at $28^{\circ} \mathrm{C}$ for 28 days to get a pleasant taste of galanga-pickled white shrimp (Litopenaeus vannamei).

Table 6: Effect of fermentation temperature and time to amino acid, $\mathrm{pH}$, water activity and sensory score of the galanga-pickled white shrimp (Litopenaeus vannamei)

\begin{tabular}{lcccc}
\hline Fermentation & Amino acid $(\mathrm{g} / 100 \mathrm{~g})$ & $\mathrm{pH}$ & Water activity $\left(\mathrm{a}_{\mathrm{w}}\right)$ & Sensory score \\
\hline $26^{\circ} \mathrm{C}: 30$ days & $48.59 \pm 0.00^{\mathrm{b}}$ & $4.39 \pm 0.02^{\mathrm{bc}}$ & $0.63 \pm 0.02^{\mathrm{bc}}$ & $8.76 \pm 0.01^{\mathrm{ab}}$ \\
$28^{\circ} \mathrm{C}: 28$ days & $49.74 \pm 0.00^{\mathrm{a}}$ & $4.35 \pm 0.01^{\mathrm{c}}$ & $0.62 \pm 0.01^{\mathrm{c}}$ & $8.85 \pm 0.02^{\mathrm{a}}$ \\
$30^{\circ} \mathrm{C}: 26$ days & $47.38 \pm 0.03^{\mathrm{c}}$ & $4.41 \pm 0.03^{\mathrm{b}}$ & $0.66 \pm 0.02^{\mathrm{b}}$ & $8.10 \pm 0.02^{\mathrm{b}}$ \\
$32^{\circ} \mathrm{C}: 24$ days & $46.14 \pm 0.01^{\mathrm{d}}$ & $4.46 \pm 0.02^{\mathrm{ab}}$ & $0.68 \pm 0.01^{\mathrm{ab}}$ & $7.69 \pm 0.01^{\mathrm{c}}$ \\
$34^{\circ} \mathrm{C}: 22$ days & $45.28 \pm 0.02^{\mathrm{e}}$ & $4.50 \pm 0.02^{\mathrm{a}}$ & $0.70 \pm 0.03^{\mathrm{a}}$ & $7.22 \pm 0.00^{\mathrm{d}}$ \\
\hline
\end{tabular}

Note: the values were expressed as the mean of three repetitions; the same characters (denoted above), the difference between them was not significant $(\alpha=5 \%)$.

Fermentation was one of the preservative approaches to maintain the stability of the seafood storage for long time ${ }^{26}$. Shrimp paste was produced by mixing with salt to ferment at ambient temperature ${ }^{8}$.

\section{Shelf-life of the galanga-pickled white shrimp (Litopenaeus vannamei) during storage}

Galanga-pickled white shrimp (Litopenaeus vannamei) products were kept in ambient temperature condition $\left(28 \pm 2^{\circ} \mathrm{C}\right)$. Amino acid $(\mathrm{g} / 100 \mathrm{~g})$, $\mathrm{pH}$, water activity (aw), sensory score were used as quality indicators by sampling in 3 months interval for 12 months. From Table 7, quality of galanga-pickled white shrimp (Litopenaeus vannamei) was nearly stable at ambient temperature $\left(28 \pm 2^{\circ} \mathrm{C}\right)$ during 12 months of storage.

Table 7: Shelf-life of the galanga-pickled white shrimp (Litopenaeus vannamei) during storage

\begin{tabular}{ccccc}
\hline Preservation (months) & Amino acid $(\mathrm{g} / 100 \mathrm{~g})$ & $\mathrm{pH}$ & Water activity $\left(\mathrm{a}_{\mathrm{w}}\right)$ & Sensory score \\
\hline 0 & $49.74 \pm 0.00^{\mathrm{c}}$ & $4.35 \pm 0.01^{\mathrm{a}}$ & $0.62 \pm 0.01^{\mathrm{a}}$ & $8.85 \pm 0.02^{\mathrm{ab}}$ \\
3 & $49.80 \pm 0.01^{\mathrm{bc}}$ & $4.32 \pm 0.00^{\mathrm{ab}}$ & $0.62 \pm 0.02^{\mathrm{a}}$ & $8.88 \pm 0.01^{\mathrm{a}}$ \\
6 & $49.97 \pm 0.02^{\mathrm{b}}$ & $4.31 \pm 0.01^{\mathrm{b}}$ & $0.60 \pm 0.01^{\mathrm{ab}}$ & $8.80 \pm 0.02^{\mathrm{b}}$ \\
9 & $50.18 \pm 0.02^{\mathrm{ab}}$ & $4.30 \pm 0.04^{\mathrm{bc}}$ & $0.59 \pm 0.03^{\mathrm{ab}}$ & $8.77 \pm 0.03^{\mathrm{bc}}$ \\
12 & $50.33 \pm 0.04^{\mathrm{a}}$ & $4.28 \pm 0.01^{\mathrm{c}}$ & $0.57 \pm 0.01^{\mathrm{b}}$ & $8.75 \pm 0.01^{\mathrm{c}}$ \\
\hline
\end{tabular}

Note: the values were expressed as the mean of three repetitions; the same characters (denoted above), the difference between them was not significant ( $\alpha=5 \%$ ).

During pickling process, a large quantity of specific amino acid was produced. Seafood pickle was safe without any toxic bacteria and maintaining durable stability over 6 months at room temperature ${ }^{16}$. The preparation of pasteurized marinated shrimp in green curry paste was safe for human consumption until the end of storage period for 15 days at $0-3^{\circ} \mathrm{C}^{27}$.

\section{CONCLUSION}

Pickling is one of the easy and safe means of shrimp preservation. Pickled shrimps create essential peptids and amino acids through autolytic and fermented reaction during the fermentation. However there was not any research mentioned to production of pickle white shrimp (Litopenaeus vannamei). The main production of this product is salt adding, fermenting, and curing. We have successfully examined different factors affecting to production of galanga-pickled white shrimp (Litopenaeus vannamei). By preserving under ambient temperature $\left(28 \pm 2^{\circ} \mathrm{C}\right)$, the galangal-picked shrimp could be maintained shelflife for 12 months without any preservative. This simple technology can be easily approached to process in household scale. 


\section{ACKNOWLEDGEMENT}

We acknowledge the resources and financial support for the study was provided by
Nguyen Tat Thanh University, Vietnam.

\section{Conflict of Interest}

Conflict of interest declared none.

\section{REFERENCES}

1. Gunalan, B.;NinaTabitha, S.;Soundarapandian, P.; and Anand, T. Nutritive value of cultured white leg shrimp Litopenaeus vannamei. International Journal of Fisheries and Aquaculture., 2013, 5, 166-171.

2. Syama Daya, J.; Ponniah, A. G.; Imran Khan, H.; Madhu Babu, E. P.; Ambasankar, K. and Kumarguru Vasagam, K. P. Shrimps-a nutritional perspective. Current Science., 2013, 104, 1487-1491.

3. Anirban Chouni; Santanu Paul. A review on phytochemical and pharmacological potential of Alpinia galanga. Pharmacogn J., 2018, 10, 9-15.

4. Yu JG. Identifcation of the chemical components of two Alpine species. Zhongyao Tong Bao Beijing, China., 1981, 13, 34-36.

5. Pal Jain, A.; Singh Pawara, R.; Lodhia, S.; Singhaia, A. Immunomodulatory and antioxidant potential of Alpinia galanga Linn. rhizomes. Pharmacogn Commun., 2012, 2, 30-37.

6. Tidaporn Chaweepack; Chutima Khomvilai; Surachart Chaweepack and Kaeko Kamei. Effect of Galangal (Alpinia galanga Linn.) Extract on the growth rate and resistance to Vibrio harveyi and white spot diseases in Pacific white shrimp (Litopenaeus vannamei). Journal of Agricultural Science., 2015, 7, 117-128.

7. Faithong, N.; Benjakul, S.; Phatcharat, S.; Binson, W. Chemical composition and antioxidative activity of Thai traditional fermented shrimp and krill products. Food Chem., 2010, 119, 133-140.

8. Ernestina, M.; Peralta; Hideo Hatate; Daisuke Watanabe; Daisuke Kawabe; Hisashi Murata; Yoichiro Hama and Ryusuke Tanaka. Antioxidative Activity of Philippine SaltFermented Shrimp and Variation of Its Constituents during Fermentation. Journal of Oleo Science., 2005, 54, 553-558.

9. Amnat Pakdeeto; Somboon Tanasupawat;
Chitti Thawai; Somporn Moonmangmee; Takuji Kudo and Takashi Itoh. Lentibacillus kapialis sp. nov., from fermented shrimp paste in Thailand. International Journal of Systematic and Evolutionary Microbiology ., 2007, 57, 364-369.

10. Hajeb, $P$; and Jinap, S. Fermented Shrimp Products as Source of Umami in Southeast Asia. Journal of Nutrition \& Food Sciences., 2012, 10, 1-5.

11. Young-Boong Kim; Yun-Sang Choi; SuKyung Ku; Dai-Ja Jang; Hajah Hasnah binti Ibrahim; Ki Bong Moon. Comparison of quality characteristics between belacan from Brunei Darussalam and Korean shrimp paste. Journal of Ethnic Foods., 2014, 1, 19-23.

12. Luyun Cai; Qingjun Wang; Zhijian Dong; Shucheng Liu; Chaohua Zhang and Jianrong Li. Biochemical, nutritional, and sensory quality of the low salt fermented shrimp paste. Journal of Aquatic Food Product Technology., 2017, 26, 706-718.

13. Durve, V.S. and Bal, D.V. Studies on the chemical composition of the oyster Crassostrea gvphoides (Schlothecium). Journal of Zoological Society of India., 1962, 13, 70 -72.

14. Giese, A.C. Canning of edible oyster meat. Physiological Reviews., 1966, 46, 244-248.

15. Ansari, Z.A.; Parulekhar, A.H.; and Natondkhar, S.G.P.Nutritional studies of fishes. Indian Journal of Marine Sciences., 1981, 10, 128 - 136.

16. Chandrashekhar, T.C.A method ofprocessing and preservation of prawn pickle. Seafood Export Journal., 1979, 11, 15-18.

17. Karunasagar Indrani; Vanugopal, M. N.; Jayashekharan, G.; Sekar, K.; and Karunasagar, I. Microoganisms associated with prawn pickle spoilage. J. Food Sci. Technol., 1989, 25, 103-104. 
18. Jawahar Abraham, A.; Rathinakumar, K.; and Jeyachandran, P. Microbiological characteristics of prawn pickle. Fishery Technology., 1996, 33, $111-115$.

19. Kumar, S. and Basu, S. Preparation of prawn pickle and its storage characteristics. Journal of the Indian Fisheries Association., 2001, 28, 105-111.

20. Shuling Xiong; Youling L. Xiong; Suzanne P. Blanchard; Baowu Wang; James $\mathrm{H}$. Tidwell. Evaluation of tenderness in prawns (Machrobrachium rosenbergii) marinated in various salt and acid solutions. International Journal of Food Science and Technology ., 2002, 37, 291-296.

21. Sunisa Siripongvutikorn; Naiyana Pengseng; Sujira Ayusuk; and Worapong Usawakesmanee. Development of green curry paste marinade for white shrimp (Litopenaeus vannamei). Songklanakarin $\mathrm{J}$. Sci. Technol., 2008, 30, 35-40.

22. Nor Salasiah Mohamed and Jirarat Anuntagool. Effects of pasteurization at different temperature and time on marinated shrimp in green curry. Malaysian Journal of Analytical Sciences., 2015, 19, 739 - 744.

23. Suryanarayana Rao S. V.; Valsan, A. P.; and Rajemjranathan Nayar M. Studies on the preservation of fish by pickling. Indian Journal of Fisheries., 1958, 1, 327-340.

24. Kreuzer, R. Investigation of biological factors causing spoilage of fish products and its effect on organism and environment. Fisheries., 1990, 8, 104-109.

25. Saritha, K.; Immaculate Jeyasanta, K.; and Jamila Patterson. Physico-chemical and sensorial characteristics of commercial seafood pickles of Tuticorin super markets, Tamil Nadu, India. International Food Research Journal., 2014, 21, 649-654.

26. Jamila Patterson, P.; and Ayyakannu, K. Pickled product from a gastropod Babylonia spirata, Fishery Technology., 1997, 34, 45-48.

27. Jawahar, A.T.; and Shetty, T.M.R. Effect of sodium benzoate on the fermentative fish pickle. Fishery Technology., 1994, 3l, 48- 51. 